Svitlana Bondarenko, Mykola Tkach, Anatolii Polishchuk, Mykhailo Mosin (2019) Retrospektyvnyy analiz lohistychnykh kontseptsiy upravlinnya resursnymy potokamy [Retrospective analysis of logistic concepts of resource management]. Social development \& Security. 9(4), 21 - 40. DOI: http://doi.org/10.33445/sds.2019.9.4.2

\title{
Ретроспективний аналіз логістичних концепцій управління ресурсними потоками
}

\author{
Світлана Бондаренко *, Микола Ткач **, Анатолій Поліщук ***, Михайло Мосін **** \\ * Інститут проблем ринку та економіко-екологічних досліджень НАН України, \\ Франиузький бульвар, 29, м. Одеса, 65044, Україна, \\ e-mail: lana.bond@ukr.net, \\ д.e.н., \\ старший науковий співробітник відділу економічних механізмів і структур.
}

** Національний університет оборони Украӥни імені Івана Черняховського, проспект Повітрофлотський, 28, м. Київ-049, 03049, Україна,

e-mail:nyck1985@ukr.net,

к.m.H.,

старший викладач кафедри економіки та фінансового забезпечення.

*** Національний технічний університет Украйни «Київський політехнічний інститут імені Ігоря Сікорського», проспект Перемоги, 37, м. Київ-056, 03056, Украӥна,

e-mail: avalonanatoly@gmail.com,

здобувач кафедри міжнародної економіки.

*** Національний технічний університет Украӥни «Київський політехнічний інститут імені Ігоря Сікорського», проспект Перемоги, 37, м. Київ-056, 03056, Украӥна,

e-mail:mosin-ussz@ukr.net,

здобувач кафедри міжнародної економіки.

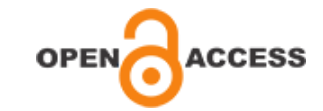

Article history:

Received: June, 2019

1st Revision: July, 2019

Accepted: August, 2019

УДК 658.8(075.8)

\begin{abstract}
Анотація: Метою статті є дослідження розвитку логістичних концепцій управління ресурсними потоками на підставі ретроспективного аналізу. У статті доведено, що одним із провідних факторів зміни логістичних концепцій $є$ зміна концепцій виробництва, при цьому ускладнення форм виробництва відбувається 3 ростом рівня вимог ринку, а розвиток видів і частоти такої взаємодії викликає зміну економічних парадигм. Проведено ретроспективний аналіз
\end{abstract} розвитку логістичних концепцій, їх трансформація у відповідності до зміни характеру ресурсних потоків.

Ключові слова: логістичний ланцюг товарного ринку, ресурсні потоки, управління логістичними ланцюгами.

Бібл.: 14, табл. 1, рис. 6.

\section{1. Формулювання проблеми}

Для нового етапу економічного розвитку характерним $є$ новий портфель ресурсів (основною характеристикою яких $\epsilon$ гнучкість, здатність до взаємодоповнення і взаємозаміщення, мобільність), який спирається на сервісну 
економіку. При цьому пропонується складний комплекс послуг з обслуговування традиційних галузей з метою мінімізації витрат / підвищення продуктивності праці, оптимізації бізнес-процесів і систем управління. Сервісна економіка продукує нові продукти, технології, бізнес, а, отже, нові ринки. Логістика визначає напрямки загальносвітових потоків товарів i послуг. Ефективна логістика створює конкурентні переваги на рівні ділових організацій, регіонів, національних економік, сприяє входженню на нові ринки. Логістика подовжує і диверсифікує ланцюжок створення доданої вартості, впливає на структуру національної економіки, визначаючи іiі «профіль».

В умовах інформатизації суспільства розвиток зовнішнього середовища відбувається надзвичайно швидкими темпами. Поступово змінюється суспільство, а разом з ним, і межі зміни парадигм розвитку системи стають вельми розмиті в зв'язку з еволюційним характером їх змін. Одним з провідних факторів зміни логістичних концепцій є зміна концепцій виробництва, при цьому ускладнення форм виробництва відбувається з ростом рівня вимог ринку, а розвиток видів і частоти такої взаємодії викликає зміну економічних парадигм.

\section{2 Аналіз останніх досліджень та публікацій}

У сучасній економічній системі актуалізується потреба в логістичних методах управління ринковими процесами. Дослідники виділяють такі основні проблеми логістики на сучасному етапі розвитку економіки $[1,2,3]$ :

- управління ланцюгами постачання (Supply Chain Management, SCM);

- стратегічне планування, комплексне управління якістю (total quality management, TQM);

- застосування концепції «точно в термін» (just-in-time, JIT);

- швидкого реагування (quick response, QR);

- впровадження системи ефективного реагування на запити споживачів (Efficient Consumer Response, ECR);

- інтеграція логістичних потоків вітчизняних товарних ринків у систему глобальної логістики;

- нормативно-правове i інституціональне забезпечення координації інтересів на рівні корпоративного приватного сектору, малого і середнього підприємництва і держави;

- узгодження інформаційних потоків для учасників на кожному рівні логістичних ланцюгів товарних ринків і ланцюгів попиту.

Особливої актуальності набуває організація ринкової логістики (логістикоринкові інструменти управління ресурсними потоками в товарному ринку).

Деякі аспекти логістичної координації на мікро- та макрорівні досліджували такі вчені: І. Баленко, С. Крикавський, I. Кубів, Ф. Котлер, Н. Круминш, М. Окландер, Н. Чухрай та ін. Разом 3 тим, проблеми координації взаємодії учасників ринку досі залишається не вирішеними.

\section{3. Постановка завдання}

Метою статті є дослідження розвитку логістичних концепцій управління 
ресурсними потоками на підставі ретроспективного аналізу.

\section{2. Виклад основного матеріалу}

Для реальної економіки характерні два протилежних механізми розподілу ресурсів: командна економіка, коли всі рішення щодо використання ресурсів $\mathrm{i}$ розподілу продуктів приймаються єдиним центральним органом, i ринкова економіка, коли розподіл ресурсів здійснюється незалежними рішеннями самостійних економічних агентів.

Економічними агентами є господарюючі суб'єкти: домогосподарства, компанії і суб'єкти господарської діяльності держави. Всі ці фактори ринкової економіки взаємопов'язані між собою реальними (товарно-матеріальними), грошовими (доходи, витрати, інвестиції, податки, субсидії, трансферти) i інформаційними потоками (відомості про ціну, партнерах, конкурентах, попит, пропозицію). Їх взаємозв’язки і співвідношення визначають ефективність тієї чи іншої моделі ринкової економіки, перспективи розвитку суб’єкта (держави, регіону, галузі). Для балансування розвитку економіки важливим $\epsilon$ урегульованість характеру взаємодії економічних агентів - урівноваженість сукупного випуску товарів (сукупної пропозиції) і сукупного попиту засобами урівноваження цін. Схема взаємодії сукупного попиту і сукупної пропозиції 3 виділенням основних видів ресурсів представлена на рис. 1.

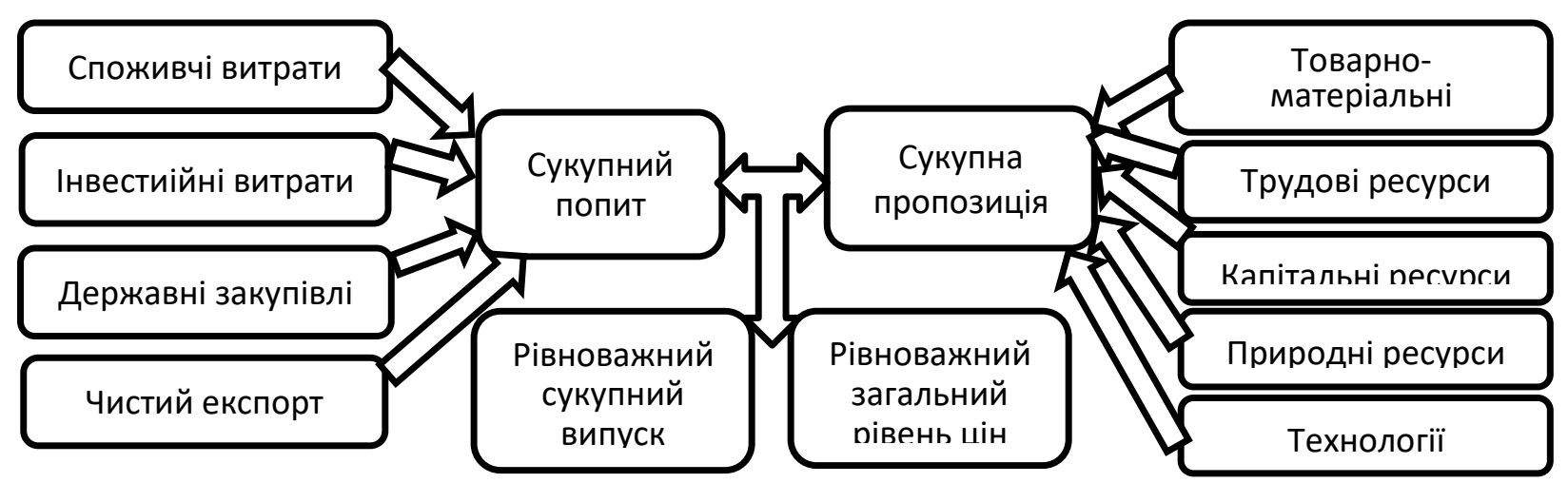

Рис. 1. Схема взаємодії сукупного попиту і сукупної пропозиції з виділенням основних видів ресурсів

Джерело: складено автором на основі $[4$, с. 60]

Оскільки основою ринкової економіки $є$ приватна власність, у т.ч. і на ресурси, регуляторний вплив має бути направлений на ресурсні потоки. Поняття «ресурсні потоки» характеризує економічні процеси, які відбуваються неперервно і вимірюється в одиницях за певний період часу.

В моделі ринку, як макроекономічної системи, розглядаються кругообіг потоків продукції (товарів), витрат, доходів (економічних благ). Модель кругообігу ресурсних потоків i економічних благ для відкритої економіки представлена на рис. 2.

Дана модель включає державний сектор, який формує національні інтереси, i закордонний сектор, який, в умовах глобалізації має особливий вплив на 
протікання усіх внутрішніх процесів ринкової системи. У даній моделі представлено об’ єктне подання логістичного ланцюга товарного ринку (ЛЛТР). ЛЛТР - лінійно упорядкована сукупність взаємопов'язаних ланок з переміщення товарно-матеріальних цінностей (сировина - готова продукція - складування товарна партія - розподіл - реалізація - споживання), яка реалізує відтворювальну функцію товароруху на ринку.

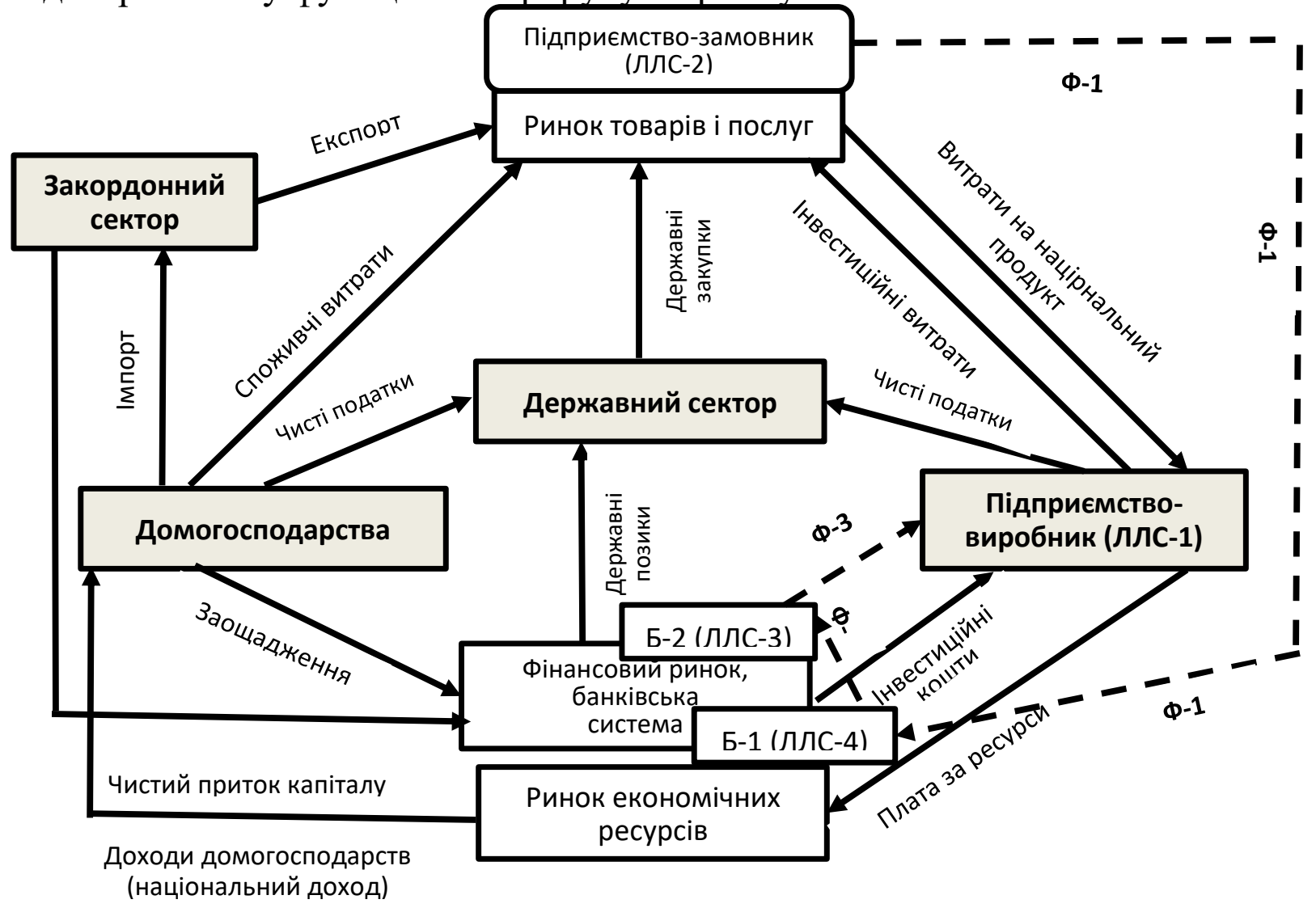

- - - фінансові потоки; $Ф$-1 - фінансові потоки від підприємства-замовника до банка підприємста-замовника; Б-1 -банк підприємства-замовника; Б-2 -банк підприємства-виробника; Ф2 - фінансові потоки від банк підприємства-замовника до банка підприємста- виробника; Ф-3 фінансові потоки від банка підприємста-виробника до підприємста-виробника; ЛЛС - ланки логістичної системи.

Рис. 2. Модель кругообігу ресурсів і економічних благ для відкритої економіки Джерело: складено автором на основі [4, с. 60]

Також у межах моделі схематично зображено фінансові потоки. Тобто сукупність логістичних ланцюгів товарних ринків представляє собою логістичну систему, до складу якої входять підсистеми, ланки та елементи, які пов'язані між собою за принципом вкладеності (кожен наступний елемент є сукупністю безлічі більш дрібних складових) або мереж і каналів, що відповідає вимогам побудови логістичної інфраструктури в розрізі реалізації функцій товароруху. Коротка характеристика різних підходів до трактування поняття ЛЛТР, його елементів i структури, i відповідно, до управління такими ланцюгами представлена в табл. 1. [5].

Для ЛЛТР характерна відтворювальна функція товароруху - забезпечення 
постійно повторюваного обігу товарно-матеріальних цінностей в межах товарного ринку, яке спрямовано на ефективне функціонування ринку: балансування попиту та пропозиції; адаптацію параметрів товарних потоків до заходів державного регулювання ринків; відновлення недостатніх секторів ринків; забезпечення рівних умов конкуренції між суб’єктами ринкових відносин; прискорення товарообігу, тощо.

Таблиця 1

Підходи до управління логістичними ланцюгами товарного ринку в залежності від об'скта управління

\begin{tabular}{|l|l|l|}
\hline Підхід до управління & \multicolumn{1}{|c|}{ Об'єкт управління } & \multicolumn{1}{|c|}{ Обмеження управління } \\
\hline Потоковий & $\begin{array}{l}\text { Товарно-матеріальні, } \\
\text { фінансової, правові, } \\
\text { інформаційні потоки. } \\
\text { Логістичнй потік } \\
\text { товарного ринку }\end{array}$ & $\begin{array}{l}\text { Складність забезпечення єдиних } \\
\text { підходів до управління на стиках } \\
\text { логістичних систем учасників ринку }\end{array}$ \\
\hline $\begin{array}{l}\text { Функціонально- } \\
\text { процесний }\end{array}$ & $\begin{array}{l}\text { Функції і/або бізнес- } \\
\text { процеси }\end{array}$ & $\begin{array}{l}\text { Неузгодженість методології } \\
\text { процесного управління з об'єктами } \\
\text { управління логістики - потоками }\end{array}$ \\
\hline Організаційний & $\begin{array}{l}\text { Учасники ринку, взаємодія } \\
\text { і взаємозв'язок між ними }\end{array}$ & $\begin{array}{l}\text { Складність координації діяльності } \\
\text { юридично незалежних учасників } \\
\text { ринку }\end{array}$ \\
\hline Об'єктний & $\begin{array}{l}\text { Складові ЛлтР } \\
\text { (логістичної системи): } \\
\text { підсистеми, ланки, } \\
\text { елементи, канали, ланцюги } \\
\text { тощо }\end{array}$ & $\begin{array}{l}\text { Певною мірою ігноруються такі } \\
\text { важливі аспекти функціонування } \\
\text { ЛлТР, як процеси, заради яких вони } \\
\text { утворюються, та відношення між } \\
\text { учасниками, завдяки яким } \\
\text { реалізуєтья їх формування }\end{array}$ \\
\hline
\end{tabular}

Джерело: складено автором на основі $[5,6]$

Фахівці з логістики та менеджменту не прийшли до єдиної думки щодо визначення та змісту поняття «управління ЛЛТР». Інколи застосовують цей термін як синонім логістики або інтегрованої логістики. Однак зараз акцент у тлумаченні цієї концепції все більше зміщується в бік розширеного розуміння Supply Chain Management (SCM) як нової концепції бізнесу, застосування основних аспектів для управління ЛЛТР (переміщення фокусу 3 мікро- на макрологістику). Американські вчені Д. Ламберт і Дж. Сток так визначають це поняття: «Управління логістичними ланцюгами - інтегрування ключових бізнеспроцесів, що починаються від кінцевого користувача i охоплюють усіх постачальників товарів, послуг і інформації, що додають цінність для споживачів i інших зацікавлених осіб». Вони вказують, що управління логістичними ланцюгами - це інтеграція восьми ключових бізнес-процесів:

1) управління взаємовідносинами з споживачами;

2) обслуговування споживачів;

3) управління попитом;

4) управління виконанням замовлень;

5) підтримки виробничих процесів;

6) управління постачанням; 
7) управління розробкою продукції i iï доведенням до комерційного використання;

8) управління поворотними матеріальними потоками.

Деякі вітчизняні дослідники розглядають SCM як логістичну координацію, як впорядкування різних логістичних операцій і правил їх виконання.

Отже, управління логістичними ланцюгами можна охарактеризувати, як оптимізацію бізнес-процесів як усередині організації, так і на міжорганізаційному рівні, що забезпечують цілеспрямований рух потокових процесів в логістичних системах. Такий підхід більше торкається мікрологістики.

У процесі управління логістичними ланцюгами виділяють 5 етапів: планування, закупівля, виробництво, збут, післяпродажне обслуговування (сервіс). Для досягнення значних результатів по виділеним напрямкам, необхідно вирішити такі завдання:

- скоротити цикл і горизонт планування на основі використання ефективних інформаційних систем;

- оптимізувати витрати за рахунок оптимального вибору закуповуваних виробів і їх постачальників, взаємодії з ними в режимі реального часу;

- знизити трансакційні витрати через оптимізацію потоків продукції і оперативного обміну інформацією між контрагентами;

- знизити складські витрати за рахунок приведення обсягів виробництва, відповідно до попиту;

- підвищити якість обслуговування споживачів за рахунок оперативності та гнучкості процесу постачання.

Учасники логістичних ланцюгів, взаємодіючи між собою, встановлюють зв'язки, які за ступенем їх підконтрольності, умовно можна розділити на 4 типи: керовані зв'язки; некеровані зв'язки; відслідковувані зв'язки; зв'язки, 3 об'єктами, що не входять в логістичний ланцюг [5].

Управління ЛЛТР направлено на руйнування усіх бар'єрів, що зустрічаються на шляху потоку у різних учасників ланцюга постачання. В даний час критичними факторами успіху в конкурентній боротьбі є сервіс поставки i оптимальні витрати на здійснення робіт зі створення матеріальних благ i цінностей в ланцюзі як в єдиному цілому. Досягнення цієї мети забезпечується синхронізацією виконання робіт всіма учасниками ланцюга i безперервної спрямованістю на задоволення споживачів.

Аналіз теоретичних досліджень безпосередньо в області логістики i управління ланцюгами постачання (Supply Chain Management, SCM) дозволяє виділити основні етапи їх розвитку та уточнити систему термінів, які використовуються в даній області знань [6-9]. На думку дослідників [10-12] виділяють поетапний розвиток семи економічних парадигм, починаючи з 1960-х pp. На рис. 3 узагальнено трансформаційні зміни виробничо-логістичних концепцій, у відповідності до еволюції парадигм розвитку ринкової економіки.

Згідно схеми, представленої на рис. 3, відбувається поступовий перехід від «ринку виробника» до «ринку споживача», від виробництва, орієнтованого виключно на продуктивність, до складних форм організації виробництва, від 
підходу «відособлення» до нарощування процесів інтеграції учасників ланцюга створення цінності, що призводить до утворення ланцюгів і мереж постачання.

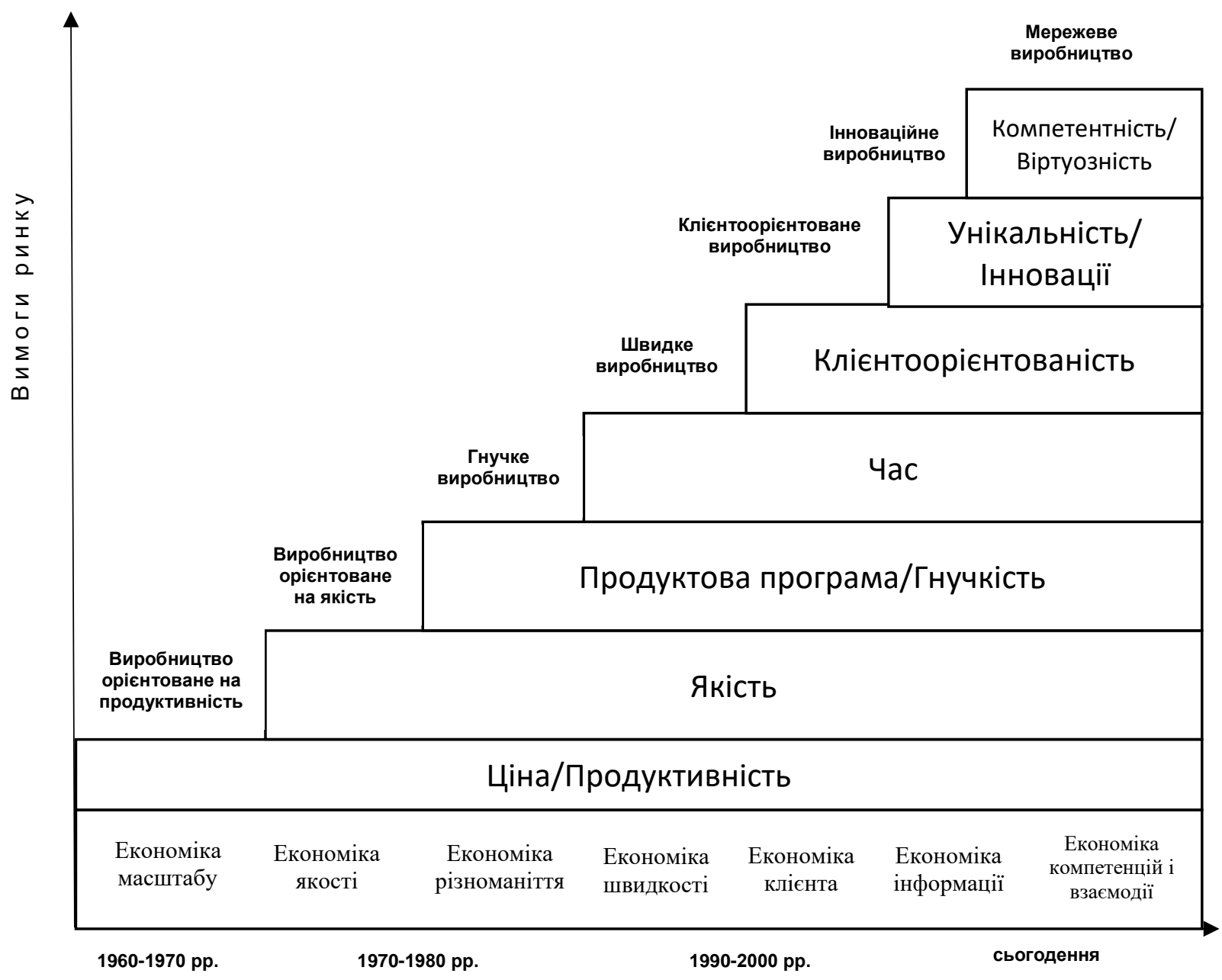

Рис. 3. Еволюція парадигм розвитку ринкової економіки Джерело: складено автором на основі $[9,10]$

На протязі 1960-1970-і рр. розвиток виробництва визначався ефектом масштабу, тобто скорочення середніх витрат при нарощуванні обсягу виробництва. В цей період основною метою виробничого підприємства було скорочення витрат. Для реалізації поставлених завдань застосовувався регулярний менеджмент, заснований на функціональній моделі управління. Концепція бізнес-логістики в якості інтегрального інструменту менеджменту 3'явилася на Заході в кінці 60-х років XX століття і розглядала логістику як менеджмент усіх видів діяльності, що сприяють досягненню i координації попиту і пропозиції на товари в певному місці і в заданий час.

В кінці 1950-х - початку 1960-х американський вчений А. Фейгенбаум вперше в своїх роботах ввів термін «Загальний контроль якості» (TQC - Total Quality Control) [7]. Ця ідея набула своєї практичної реалізації в Японії, де у 1961 році компанією Тoyota була впроваджена концепція загального контролю якості, а через три роки модифікована модель досягла величезного успіху ще і в США та Європі, поступово поширюючись на інші галузі виробництва. Даний етап означається формуванням базової концепції управління та інформаційно- 
технологічної логістичної концепції, що веде до ускладнення інформаційних систем, які автоматизують матеріальні потоки.

Перехід до парадигми різноманіття пов’язують з кризою 1974-1975 pр.

Основними змінами, які відбулися у світовій економіці внаслідок кризи, стали: (1) початок нового етапу розвитку капіталізму, (2) зростання інтернаціоналізації виробництва, (3) підвищення ролі спеціалізації і (4) міжнародний поділ праці. В цей період відбувся значний спад виробництва (навіть в країнах, які пережили так зване «економічне диво»). Породжене таким спадом зростання цін призвело до переорієнтації виробничих підприємств на випуск більш рентабельної продукції. Диверсифікація стала головним стратегічним пріоритетом в даний період. Це стало можливим завдяки концепції гнучкого виробництва. Гнучке виробництво (flexible) характеризується виробничої гнучкістю (flexibility) [8].

Ускладнення задач, згідно принципів гнучкого виробництва, привело до поширення нових інструментів i технологій, які дали можливість швидко переходити на випуск іншого виробу при мінімальному часі простою обладнання, а також впровадити більш диференційовані організаційні структури (децентралізація, аутсорсинг, підряди i субпідряди). Щодо автоматизації виробництва даного етапу, слід указати на автоматизовані системи управління (ACУ) типу FMS (Flexible Manufacturing System - гнучка виробнича система), під якими розуміються комплекси обладнання з числовим програмним управлінням (ЧПУ) в різних їх поєднаннях і пов'язаних один 3 одним централізованою системою управління.

У системах управління підприємствами застосовуються різні методи управління, засновані на конкретних алгоритмах підготовки i прийняття управлінських рішень 3 використанням інформаційних технологій. Автоматизація торкалася безпосередньо матеріального потоку на виробництві. Методи управління формалізовані у вигляді стандартів управління, які є основою розробки функціональної структури IC (організаційно-економічної підсистеми):

- планування потреби в матеріалах (Material Requirement Planning, MRP I);

- планування потреби в виробничих потужностях (Capacity Resource Planning, CRP);

- замкнутий цикл планування матеріальних ресурсів (CL MPR);

- планування ресурсів виробництва (Manufacturing Resource, MRP II).

- виробництво на світовому рівні (World Class Manufacturing, WCM);

- планування ресурсів підприємства (MRPII \& FRP (Finance Resource Planning), Enterprise Resource Planning, ERP I);

- оптимізації управління ресурсами (ERP II);

- менеджмент як співпраця (Customer Relationship Management, CRM, Customer Synchronized Relationship Management, CSRM).

Щодо автоматизації ключових і допоміжних процесів виробництва даного етапу економіки, слід відмітити розвиток методу MRP-CL i інформаційних систем, що підтримують даний метод. Додаткові функції і облік зворотного зв'язку забезпечують гнучкість планування 3 урахуванням зовнішніх економічних чинників (рівень попиту, стан відкритих замовлень, рух 
матеріального потоку і т.ін.). У 90-х р.p. Gartner Group вводить поняття ERP систем другого покоління - ERP II, яка характеризує перехід від автоматизації внутрішніх бізнес-процесів компанії до вільного взаємодії компанії зі своїми контрагентами. Користувачами ERP II-систем є внутрішні і зовнішні компанії всіх секторів і сегментів ринку. Це формує єдиний інформаційний простір для прийняття управлінських рішень. Такі підходи знайшла широке застосування в епоху економіки різноманіття. Все це відповідало інформаційно-технологічній парадигмі на базі функціональної концепції управління.

Для періоду 1980-х рр. характерною тенденцією розвитку промисловості став ефект швидкості. Необхідно було швидко реагувати на запити ринку, підвищувати швидкість обслуговування. Зміна парадигми була обумовлена світовою кризою 1980-1982 рр. Актуальності набуло питання економії ресурсів. Динамічні умови економіки швидкості зумовили масштабний перехід від функціонального управління до процесного, збалансованого планування та управління в цілому всіма бізнес-процесами підприємства, що стало можливим за рахунок впровадження і використання систем класу ERP, які розвивалися 3 урахуванням вимог концепції WCM (World Class Manufacturing - Виробництво світового класу), тобто необхідно було підтримувати можливості реалізації принципів бережливого виробництва i пов'язаних 3 ним інструментів. Методологія WCM включає такі методи управління: планування «Точно в термін» (Just in Time - JIT); тотальний контроль якості (Total Quality Management - TQM); оцінка ефективності системи управління (Bench making); розвиток людських ресурсів (Human Resource Development); одиничне виробництво (Lean Manufacturing) - виробництво під конкретне замовлення; реінжиніринг бізнеспроцесів (Business Process Re-Engineering, BPR); управління потоком операцій (Workflow) і т.ін.

В цей період стратегічні пріоритети зміщуються 3 економії, за рахунок скорочення виробничих витрат, - до раціоналізації діяльності за рахунок організаційних змін всередині підприємства. Такі організаційні зміни включають: (1) фокусування на основних видах діяльності, (2) продаж інших, (3) злиття i (4) поглинання - все те, що забезпечує підвищення ефективності ланцюжка створення цінності та оптимізує портфель бізнесів компанії.

Етап зародження теорії SCM припадає на 1980-і роки. Саме в цей період виникла ідея координації потоків матеріальних ресурсів і готової продукції усіх організацій, пов'язаних між собою технологічно, а не тільки в рамках одного підприємства. В цей період поняття «управління ланцюгами постачання» практично повністю відповідало поняттю «інтегрована логістика». Нова бізнесстратегія передбачає ефективні способи взаємодії з клієнтами. Такий підхід дозволяє клієнту ставати ланкою логістичного ланцюга, що залучає його у внутрішні бізнес-процеси. Таким чином, розробляється єдина логістична стратегія, яка дозволяє управляти взаємовідносинами з клієнтами в межах SCM.

Основні положення концепції SCM:

- вартість товару формується протягом усього логістичного ланцюга, i «проявляється» тільки на останній стадії - при продажу споживачеві;

- на вартість товару впливає загальна ефективність операцій, у т. ч. 
транспортних i маркетингових, усього логістичного ланцюга, a не тільки конкретно продажу;

- найбільш керованою, 3 точки зору вартості, є початкова стадія виробництво, а найбільш чутливою - останній продаж.

Завдання, які вирішуються модулем SCM:

- формування структури мережі складів сировини і готової продукції для зниження операційних логістичних витрат;

- оптимізація схеми транспортних операцій / маршрутів (з точки зору витрат);

- вибір виробника товару для поставки на конкретний регіональний ринок.

Таким чином, модуль SCM і відповідні фінансові інструменти дозволяють створити «віртуальний бізнес» 3 розподіленої системи декількох компаній, що охоплює повний життєвий цикл товару, або навпаки розділити одну компанію на кілька «віртуальних бізнесів».

Наступна парадигма характеризується формуванням клієнто-орієнтованої економіки, коли, нарівні з портфелем продуктів, з'явився портфель клієнтів із залученням споживача в процес створення цінності. Маркетингова логістична концепція стала застосовуватися 3 початку 80-х pp. ХХ ст. для побудови логістичної системи, що забезпечує конкурентоспроможність за рахунок оптимізації рішень в розподілі продукції.

Серед логістичних концепцій (технологій), широко застосовуваних у дистрибуціï, є DDT (Demand-driven Techniques / Logistics) - логістика, орієнтована на попит. Дана концепція має кілька варіантів:

- QR (Quick Response) - концепція (метод, технологія) «швидкого реагування», суть якої полягає в оцінці попиту в реальному масштабі часу $\mathrm{i}$ якомога ближче до кінцевого споживача. Реалізація даної концепції логістичного управління стала можливою після розробки відповідних інформаційних технологій, введення електронного документообігу, електронних продажів, штрихового кодування та ін. На основі інформації про попит формуються оптимальні рівні запасів і часу виконання замовлення.

- CR (Continuous Replenishment) - логістична технологія «безперервного поповнення запасів», призначена для усунення необхідності в замовленнях на готову продукцію для поповнення запасів. Ця технологія $є$ модифікацією QR. Мета - розробка плану поставки продукції роздрібним продавцям, спрямованого нам безперервне поповнення запасів. Поповнення запасів продукції у роздрібних продавців здійснює постачальник на підставі інформації про продажі, переданої продавцем.

Слід відмітити, що попередня інформаційно-технологічна парадигма стала базою для маркетингової парадигми, оскільки остання характеризується розширеним і всеосяжним використанням інформаційних технологій і систем.

Крім того, клієнтоорієнтований підхід має значний вплив і на розвиток концепцій управління якістю, з використанням методу «Шість сигм», що ставить за мету зниження відхилень у процесах таким чином, щоб забезпечити максимальну відповідність вимогам споживачів на постійній основі. 
Перша половина 1990-х років характеризується відокремленням теорії SCM від логістики. На даному етапі відбувається становлення концепції управління ланцюгами поставок (SCM) як самостійного наукового напрямку, виникає необхідність систематизувати застосовуються в логістиці та управлінні ланцюгами поставок поняття і терміни.

У другій половині $1990-\mathrm{x}$ - початку 2000 -х років формується класична концепція SCM. За поняттям «управління ланцюгами поставок» при управлінні матеріальним потоком закріплюються функції координації, планування та контролінгу. Основні дослідження спрямовані на процеси інтеграції, формування стратегічних партнерських відносин, на співпрацю i взаєморозуміння в ланцюзі постачань, інформаційну взаємодію, забезпечення комунікацій між ланками утворюють ланцюг постачання.

Логістика пропонує цілий перелік послуг і сервісів (рис. 4).

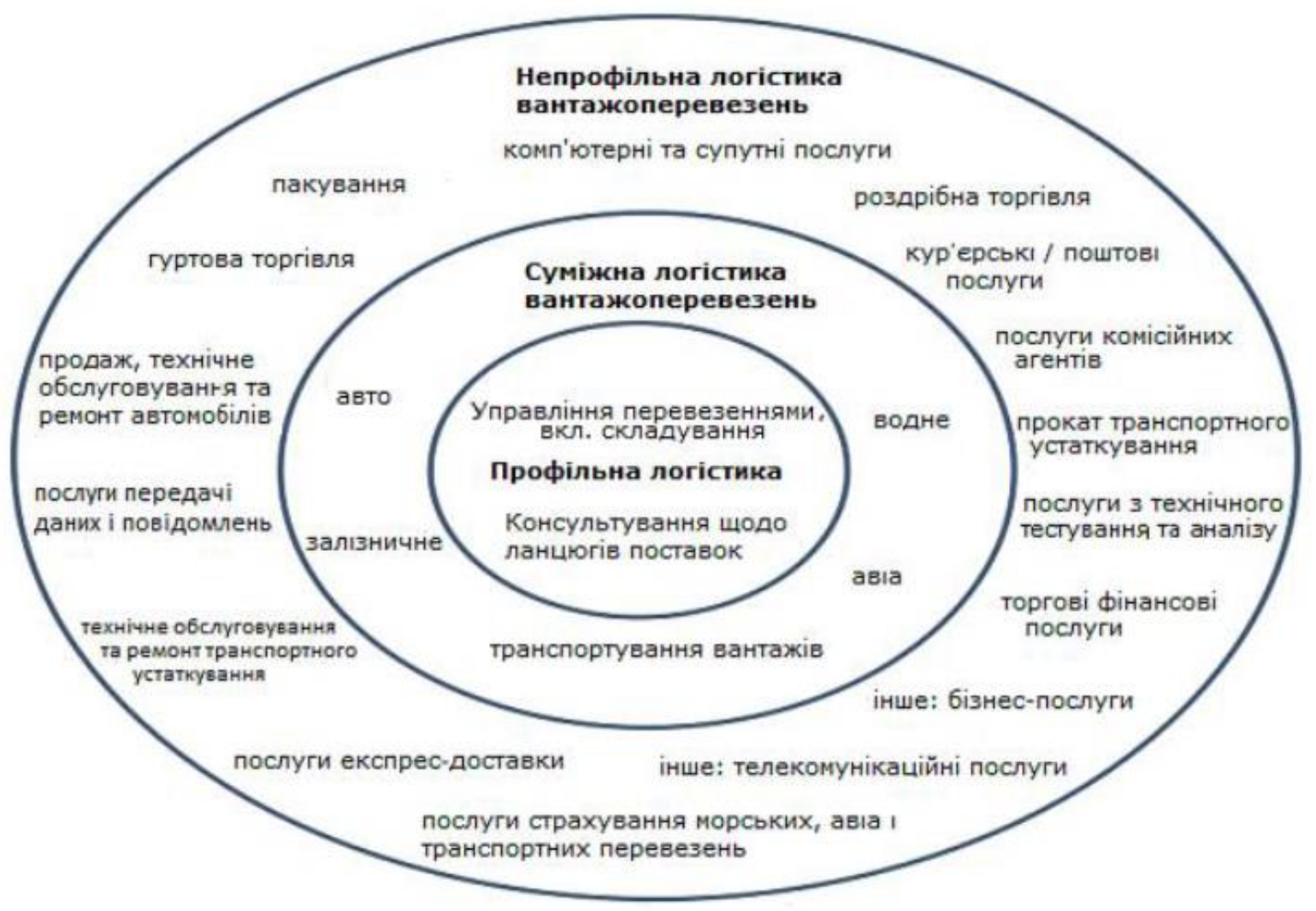

Рис. 4. Сервіс і послуги, які пропонує логістика

Джерело: [13]

Інтеграція та глобалізація суспільства вимагають максимальної інтеграції і техніко-технологічної спрямованості подальшого розвитку логістики. Управління потоками здійснюється на національному, регіональному та глобальному рівні (наприклад, єврологістіка). Логістика є стимулюючим фактором залучення інвестицій, розвитку товарних ринків (рисунок 5).

В межах системного підходу, стали виділяти логістику на мікро-, мезо- i макрорівні. Мезологістичні системи представлені інтегрованими утвореннями, які діють у вигляді між- і внутрішньогалузевих структур, різного роду об’єднань, 
корпорацій, асоціацій, холдингів. На великих промислових підприємствах (наприклад, автомобілебудування, переробної промисловості) функціонують мікрологістичні системи організації руху матеріальних потоків. Розвиток транснаціональних корпорацій, зростання концентрації виробничої діяльності, а також підвищення зовнішньоекономічної активності суб'єктів господарювання значне пожвавили розвиток макрологістичних систем, які охоплюють підприємства та організації промисловості, посередницькі, торгові і транспортні організації різних відомств, розташованих в різних регіонах країни або в різних країнах.

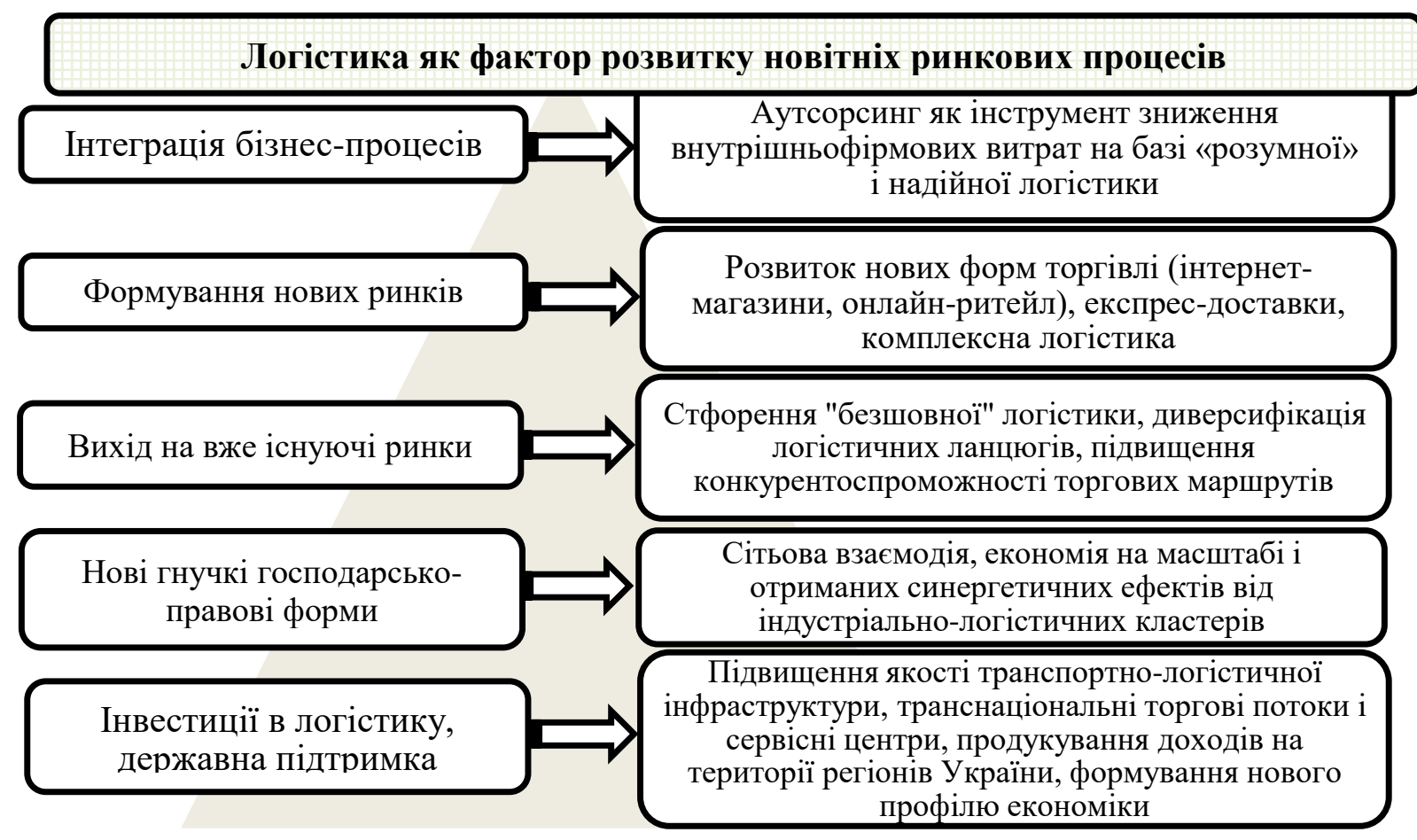

Рис. 5. Вплив логістики на розвиток новітніх ринкових процесів Джерело: розроблено автором

Також поточний етап розвитку логістики характеризується виникненням інституційних структур і господарюючих суб'єктів, основним видом діяльності яких $\epsilon$ надання повного комплексу логістичних послуг, включаючи форму аутсорсингу і консалтингу. Ці компанії є провайдерами логістичних послуг, які ранжуються за п'ятьма рівнями (1PL, 2PL, 3PL, 4PL, 5PL), яким передається частина або всі логістичні функції, в основному невиробничого характеру.

На рис. 6 представлена класифікація логістичних компаній у взаємозв'язку 3 пірамідою рівнів логістичних операцій (модель Морана-Стенлі).

Рівні логістичних провайдерів (PartyLogisticsProvid-ers) залежать від ступеня інтегрованості логістичної мережі, що обумовлюється наявністю власних ресурсів, можливостями i технологіями, а також ресурсами постачальників додаткових послуг, які здатні забезпечити повне i вичерпне рішення щодо логістичного ланцюга компанії. 


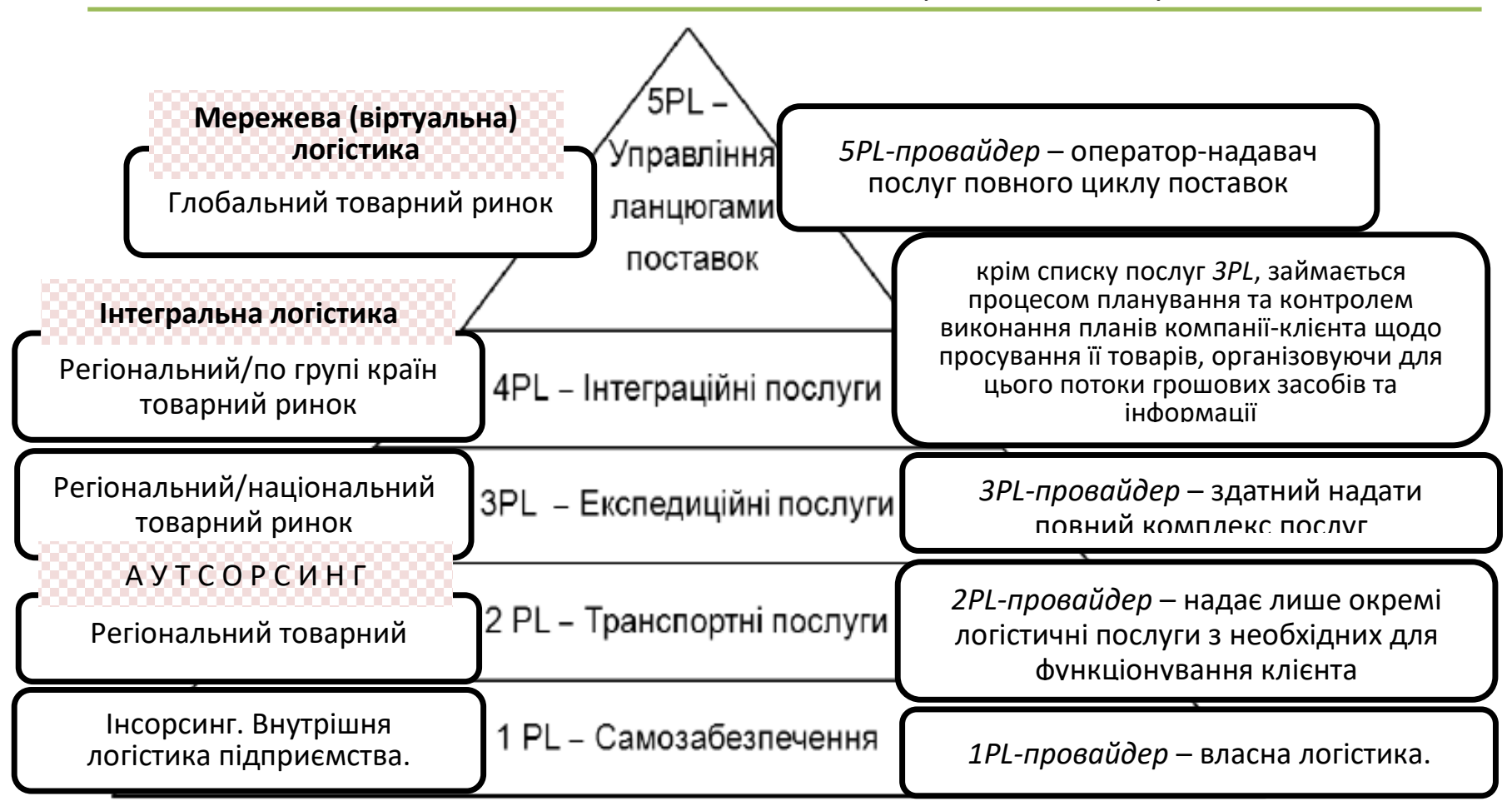

Рис. 6. Класифікація логістичних компаній за територіальним охопленням ринків, згідно моделі рівнів логістичних операцій

Моргана - Стенлі (Morgan \& Stanley)

Джерело: складено автором на основі $[5,14,15]$

3PL, 4PL, 5PL логістичні оператори - це інтегратори логістичних процесів високого рівня, коли весь ланцюжок поставок контролюється і управляється одним висококваліфікованим логістичним провайдером.

Зазвичай такого типу оператори затребувані на конкурентних ринках. Їх послугами користуються транснаціональні корпорації, що виробляють високотехнологічні продукти при безперервному виробничому циклі.

Транснаціональних корпорацій, що користуються послугами 4PL-операторів, безліч, це, зокрема, Sony, Toshiba, автомобільні концерни (Ford, Daimler Chrusler) i ін. Найчастіше на аутсорсинг передаються функції складування $(73,7 \%$ фірм 3 дослідження Cap Gemini Ernst \& Young), зовнішнього транспортування $(68,4 \%)$, оформлення вантажів $(61,4 \%)$. Найрідше - управлінні відносинами з покупцями $(3,5 \%)$. Найчастіше послугами провайдерів користуються компанії таких галузей: високотехнологічний бізнес (16\%), промислове виробництво (13\%), виробництво споживчих товарів (13\%) [16].

У світовому бізнесі широко відомі великі транспортно-експедиторські компанії, фірми, зайняті експрес-доставкою (які виступають в якості комплексних логістичних (3PL) провайдерів), такі, як Shenker-BTL, TNT Group, Danzas, DHL, ASG AB, Ryder, Federal Express , UPS, Leasnay, American Express, Welchelt, SpedBertraud Faure, Carlberson, Scansped, i інші. У них є найбільші вантажні термінали і термінальні комплекси, вони інтегрують переважну частину логістичних операцій у сфері фізичного розподілу, ефективно обслуговують постачання і розподіл продукції сотень виробників і торгових компаній. Наприклад, всесвітньо відома 
фірма експрес-доставки TNT Express Worldwide, що має понад 200 відділень у багатьох країнах, пропонує клієнтам широкий спектр логістичних послуг, що включає:

- управління логістичними ланцюгами товаровиробників;

- розраховані на велику кількість користувачів складські комплекси і послуги зберігання, сортування, переробки вантажів;

- розподіл готової продукції зі спеціалізованих дистрибутивних центрів;

- логістичні екологічно чисті проекти;

- $\quad$ повернення товарів і ремонт транспортних засобів;

- $\quad$ пряме поповнення виробничих запасів виробників до початку робочого дня;

- багатопрофільне постачання запасними частинами.

Основні причини звернення до логістичних посередників в дистрибуції, тобто розвитку стратегії аутсорсингу, такі:

- можливість підвищення ефективності власної діяльності за рахунок звільнення від допоміжних неприбуткових для підприємства робіт і зосередження на основних, найбільш прибуткових видах діяльності;

- необхідність зміцнення конкурентних позицій за рахунок підвищення якості обслуговування споживачів, надання їм послуг, які підприємство не може надавати власними силами;

- прагнення знизити витрати на виконання логістичних операцій, які виконуються спеціалізованими організаціями з більш високою продуктивністю $\mathrm{i}$ точністю за рахунок ї досвіду і масштабу діяльності, наявних унікальних технологій і обладнання;

- відсутність у власного персоналу достатнього досвіду і кваліфікації для виконання окремих робіт;

- прагнення використовувати для підвищення власної конкурентоспроможності високу репутацію або популярну марку постачальника логістичних послуг.

Ризики, пов'язані з використанням аутсорсингу в логістиці:

- $\quad$ витік комерційної інформації компанії, зниження оперативності в наданні відомостей для управління підприємством;

- $\quad$ відмова підприємства від виконання деяких функцій може привести до повної залежності від зовнішніх виконавців;

- имовірність збитків через низьку якість послуг, якщо на ринку немає ефективного логістичного провайдера;

- нерозвиненість логістичної інфраструктури країни, що не дозволяє впроваджувати нові технології.

Об'єктом логістики є наскрізний ресурсний потік, проте на окремих ділянках управління ресурсними потоками в товарному ринку має свою специфіку, відповідно до чого, виділено п'ять функціональних областей логістики: закупівельна, виробнича, розподільна, транспортна та інформаційна. На розвиток логістики і ринку логістичних послуг впливають інновації за межами логістики. Нові виробництва, нові технології і нові продуктові потоки зажадають нового дизайну як глобальних ланцюгів постачань, так і глобальних ланцюгів створення 
цінності, який може не вписується в уже існуючі системи транспортування i розміщення транспортно-логістичної інфраструктури. Діюча інфраструктура не завжди дозволяє реалізувати потенціал інноваційних рішень в області поставок, що може підривати надійність надання послуг і актуалізує питання диверсифікації ланцюгів постачання. Потреба в диверсифікації обумовлена також зростанням цін на енергоносії, подорожчанням послуг транспортування продукту. Постачальники неминуче встають перед необхідністю знайти нові шляхи для розподілу / поставки продукту при нижчих витратах.

Складна архітектура логістичних взаємодій означає, що довгострокові вигоди у вигляді створення доданої вартості, приросту торгівлі та інвестицій можливі лише на основі міцної інтеграції бізнес-процесів, яка забезпечить високотехнологічний результат / продукт. Саме комплексний погляд на сучасну архітектуру логістики дозволяє уникнути перекосів у розвитку їі окремих компонентів.

Роздроблений стан компонентів логістичної системи України (територіальні та структурні диспропорції логістичної інфраструктури, нерозвиненість / невідповідність структури ринку логістичних послуг, недостатня реалізація транзитного потенціалу) є обмежуючими факторами розвитку ринку. Подолати таку фрагментарність можливо за умови створення єдиного координаційного центру розвитку логістики, що дозволить зібрати цілісну стратегію вдосконалення логістики і управляти іiі змінами на базі інформаційних технологій.

Дана інституція включить в себе світові інноваційні розробки в області логістики. В результаті з'являться цілісні уніфіковані моделі, впровадження яких у всіх секторах економіки створить платформу для більш динамічного просування по шляху гармонізації переходу на міжнародні стандарти логістичних взаємодій.

Основні позитивні ефекти впровадження інтегрованої архітектури розвитку логістики проявляться в комплексному розвитку територій i регіональних об'єднань, пов'язаних виробничих кластерів і центрів споживання, що дозволить створити нові високотехнологічні робочі місця. За таких умов очікуються нові конкурентоспроможні маршрути, транспортні коридори, транспортно-логістичні кластери, інтегровані в міжнародні геополітичні консорціуми і кооперації.

Для досягнення зазначених орієнтирів ми пропонуємо наступні кроки.

1. Розробити загальнонаціональну стратегію розвитку логістики «Управління логістичними ланцюгами товарних ринків в умовах євроінтегра-ційних процесів». Для цього необхідно:

- виявити слабкі місця і продіагностувати можливість створення відсутніх ланок, тобто фактори, які стримують використання логістики для забезпечення стійкого економічного зростання регіонів України та окремих товарних ринків;

- розробити підпрограми комплексного (взаємопов'язаного) розвитку усіх компонентів логістичної системи, включаючи їі інфраструктурне, інституціональне, інвестиційно-ресурсне і кадрове забезпечення;

- створити відповідні платформи для забезпечення можливості інтеграції бізнес-процесів в індустріально-логістичних кластерах на базі інформаційних технологій (логістичні центри, термінали, складське господарство);

- сформувати середовище, сприятливе для стратегічної взаємодії учасників логістичних ланцюгів товарних ринків для підвищення якості управління, 
скорочення загальних (трансакційних) витрат, оптимізації фінансового результату.

2. На базі торгово-промислової палати України i регіональних торговопромислових палат створити майданчики для широкого обговорення та експертної оцінки пропозицій по виробленні економічної політики, що впливає на сектор транспортно-логістичних послуг, інформаційного забезпечення та просування ефективних практик в області логістики, формування пропозицій по гармонізації і нівелювання існуючих відмінностей у застосовуваних стандартах i нормах регулювання, ліквідації прогалин нормативно-правової бази логістики та митного адміністрування.

3. Створити інституцію розвитку логістики по реалізації комплексної програми «Управління логістичними ланцюгами товарних ринків в умовах євроінтеграційних процесів», що сприятиме розробці та реалізації проектів, спрямованих на розвиток нових технологій в логістиці, формування єдиного економічного середовища і загальних стандартів в наданні логістичних послуг.

\section{3. Висновки і перспективи подальших досліджень}

Таким чином, можливості модернізації сучасної економіки, переходу на новий щабель економічного зростання безпосередньо пов'язані з логістикою, яка в даний час розглядається і як технологія вибудовування ефективної логіки ціноутворення і отримання прибутку, і як бізнес-процес, який об’єднує окремі компанії в загальну виробничу функцію, і як стратегічне управління, спрямоване на мінімізацію витрат / підвищення продуктивності праці, а також як механізм регулювання розвитку окремих товарних ринків.

Установлено, що одним з провідних факторів зміни логістичних концепцій $\epsilon$ зміна концепцій виробництва, при цьому ускладнення форм виробництва відбувається з ростом рівня вимог ринку, а розвиток видів і частоти такої взаємодії викликає зміну економічних парадигм. Основним фактором отримання конкурентної переваги на ринку стає організація і узгодження інформаційних потоків для учасників на кожному рівні ЛЛТР і ланцюгів попиту за принципами 7П / 7R, тобто реалізація підходів і підвищення важливості інформаційної логістики і логістичного сервісу. 3 цим пов'язаний розвиток інтегральної i інноваційної парадигм логістики, основною метою якої є забезпечення максимального залучення усіх ланок логістичної системи в єдиний процес ЛЛТР і інтеграція на цій основі соціально-економічної системи із зовнішнім середовищем на засадах інноваційних технологій.

\section{Author details (in Russian)}

\section{Ретроспективный анализ логистических концепций управления ресурсным потоками}

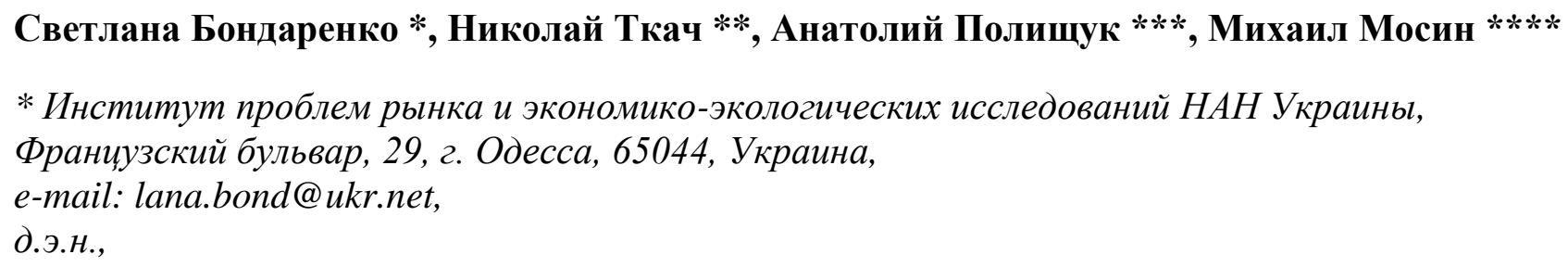


старший научный сотрудник отдела экономических механизмов и структур.

** Национальный университет обороны Украины Имени Ивана Черняховского, проспект Воздухофлотский, 28, м. Киев-049, 03049, Украина,

e-mail:nyck1985@ukr.net,

к.m.н.,

старший преподаватель кафедры экономики и финансового обеспечения.

*** Национальный технический университет Украинь» «Киевский политехнический институт имени Игоря Сикорского», проспект Победы, 37, г. Киев-056, 03056, Украина, e-mail: avalonanatoly@gmail.com,

соискатель кафедры международной экономики.

*** Национальный технический университет Украины «Киевский политехнический институт имени Игоря Сикорского», проспект Победы, 37, г. Киев-056, 03056, Украина, e-mail:mosin-ussz@ukr.net,

соискатель кафедры международной экономики.

Аннотация: Целью статьи является исследование развития логистических концепций управления ресурсными потоками на основании ретроспективного анализа. В статье доказано, что одним из ведущих факторов изменения логистических концепций является изменение концепций производства, при этом усложнение форм производства происходит с ростом уровня требований рынка, а развитие видов и частоты такого взаимодействия вызывает изменение экономических парадигм. Проведен ретроспективный анализ развития логистических концепций, их трансформация в соответствии с изменением характера ресурсных потоков. Установлено, что основным фактором получения конкурентного преимущества на рынке становится организация и согласование информационных потоков для участников на каждом уровне ЛЦТР и цепей спроса на принципах 7П / 7R, то есть реализация подходов и повышения важности информационной логистики и логистического сервиса. С этим связано развитие интегральной и инновационной парадигм логистики, основной целью которой является обеспечение максимального привлечения всех звеньев логистической системы в единый процесс ЛЦТР и интеграция на этой основе социальноэкономической системы с внешней средой на основе инновационных технологий. В статье разработаны теоретические положения по выявлению влияния логистики на развитие новейших рыночных процессов. Установлено, что недостатки развития логистической системы Украины являются значительными ограничителями развития рынка. Преодолеть указанную фрагментарность можно путем создания единого регулятора / координатора институционального центра развития логистики и управлять ее изменениями на базе информационных технологий.

Ключевые слова: логистическая цепь товарного рынка (ЛЦТР), ресурсные потоки, управление логистическими цепями.

Библ.: 14, табл. 1, рис. 6.

\title{
Author details (in English)
}

\section{Retrospective analysis of logistic concepts of resource management}

\author{
Svitlana Bondarenko *, Mykola Tkach **, Anatolii Polishchuk ***, Mykhailo Mosin **** \\ * Institute of Market Problems and Economic-Ecological Research of the NAS of Ukraine, \\ 29, Frantsuzky Boulevard, Odessa, 65044, Ukraine, \\ e-mail:lana.bond@ukr.net,
}


Dr. of Sciences,

Associate Professor, Senior Researcher of the Market Mechanisms and Structures Department.

** The National Defense University of Ukraine named after Ivan Cherniakhovskyi,

28, Povitroflotsky av., Kyiv-049, 03049, Ukraine,

e-mail: nyck1985@ukr.net,

Candidate of technical sciences (Ph.D.),

Senior Lecturer of the Department of Economics and Finance.

*** National Technical University of Ukraine, Kyiv Polytechnic Institute named after Igor Sikorsky, 37 Peremohy Ave., Kyiv-056, 03056, Ukraine,

e-mail: avalonanatoly@gmail.com,

PhD student of the Department of International Economics.

*** National Technical University of Ukraine, Kyiv Polytechnic Institute named after Igor Sikorsky, 37 Peremohy Ave., Kyiv-056, 03056, Ukraine,

e-mail:mosin-ussz@ukr.net,

PhD student of the Department of International Economics.

Abstract: The purpose of the article is to study the development of logistic concepts of resource management based on retrospective analysis. The article proves that one of the leading factors in the change in logistics concepts is a change in production concepts, while the complexity of production forms occurs with increasing market demands, and the development of the types and frequency of such interaction causes a change in economic paradigms. A retrospective analysis of the development of logistics concepts, their transformation in accordance with changes in the nature of resource flows. It has been established that the organization and coordination of information flows for participants at each level, the logistics chain of the commodity market and demand chains on the principles of 7P / $7 \mathrm{R}$, that is, the implementation of approaches and increase the importance of information logistics and logistics services, becomes the main factor for obtaining competitive advantage in the market. The development of integrated and innovative logistics paradigms is connected with this, the main goal of which is to ensure maximum involvement of all links of the logistics system into a single process, the logistics chain of the commodity market and the integration on this basis of the socioeconomic system with the external environment based on innovative technologies. The paper develops theoretical concepts for identifying the impact of logistics on the development of new market processes. It has been established that the state of the components of the logistics system, which is typical for all regions of Ukraine (significant territorial and structural disparities in the location and development of the logistics infrastructure, underdevelopment / inconsistency of the logistics services market structure with modern requirements, insufficient use of logistics management principles in the implementation of the transit potential) restrictions on the implementation of the idea of creating a common market, a single economic space, increasing returns $\mathrm{t}$ transit. This fragmentation can be overcome by creating a single regulator / coordinator - the development institute, which will allow you to put together a holistic strategy for improving logistics and managing its changes based on information technologies.

Keywords: commodity market supply chain, resource flows, supply chain management.

References: 14, tables 1, figures 6.

\section{Використана література}

1. Сток Дж.Р., Ламберт Д.М. Стратегическое управление логистикой: пер. 4-го англ. изд. М. : ИНФРА. М. 2005. 797 с.

2. Бондаренко С.А. Системне забезпечення стійкого інноваційного розвитку виноробних підприємств : монографія. НАН України, Ін-т пробл. ринку та екон.-екол. дослідж. Одеса: ІПРЕЕД НАНУ, 2018. 563 с. 
3. Колодізєва Т. О. Управління ланцюгами поставок : навчальний посібник. Харків : ХНЕУ ім. С. Кузнеця, 2016. 164 с.

4. Teich, T. Extended Value Chain Management - ein Konzept zur Koordination von Wertschöpfungsnetzen. Chemnitz: Verlag der GUC. 2003.

5. Feigenbaum, A.V. Total Quality Control (4th Edition, revised). NY: McGraw-Hill Professional. 2004.

6. Latham, A. (1996). Postfordism in the US Arms Industry: Toward "Agile Manufacturing” (YCISS Occasional Paper № 43; P. 11). Retrieved from: http://yorkspace.library.yorku.ca/ xmlui/bitstream/handle/10315/1406/YCI0065.pdf?sequence=1

7. Inman, A. Flexible Manufacturing. In Encyclopedia of Management. Retrieved from: http://www.referenceforbusiness.com/management/Ex-Gov/FlexibleManufacturing.html\#ixzz $28 \mathrm{n} 88 \mathrm{uTmH}$

8. Бондаренко С. А. Стійкий інноваційний розвиток промислового підприємства: антикризові механізми забезпечення : монографія. Харків: вид-во «ПромАрт», 2017. 607 с.

9. Nikishyna O.V., Bondarenko S.A., Liganenko I.V. The development of grape growing and gardening in Odessa region (logistic approach). // Innovative management: theoretical, methodical, and applied grounds : колективна монографія / edited by Illiashenko S.M., Strielkowski W. Prague : Prague Institute for Qualification Enhancement, 2018, P. 140-151.

10. Bondarenko S., Liganenko I. Background and problem aspects of innovative development the industrial enterprises of Ukraine // Transformational processes the development of economic systems in conditions of globalization: scientific bases, mechanisms, prospects: collective monograph / edited by M. Bezpartochnyi, in 2 Vol. / ISMA University. - Riga: «Landmark» SIA, 2018. - Vol. 1. - pp.307-327.

11. Стратегія сталої логістики та План дій для України. Проект для розгляду. URL: https://mtu.gov.ua/files/Logistics.pdf

12. Hai L. An Approach Towards Overall Supply Chain Efficiency - A Future Oriented Solution And Analysis In Inbound Process [Text] / L. Hai, S. Yirong. Göteborg University : Elanders Novum AB Pub, 2002. 87 p.

13. Characteristics of a logistics-based business model / [E. Sandberg, T. Kihlén, M. Abrahamsson] // Journal of marketing channels. 2011. № 18. P. 1-23

14. The Global competitiveness Report 2016-2017 [Electronic resource] //World Economic Forum. URL: https://www.weforum.org/reports/the-global-competitivenessreport-2016-2017-1

\section{References}

1. Stok Dzh. R., Lambert D. M. Strategicheskoye upravleniye logistikoy: per. 4-go angl. izd. Moscow : INFRA. 2005. 797 s. [in Russia]

2. Bondarenko S. A. The system of securing the innovative and innovative development of wineries: a monograph. NAS of Ukraine, Institute of Problems market and economy. doslidzh. Odessa: IPREED NASU, 2018.563 s. [in Ukrainian]

3. Kolodizova T.O. Managing supply lanceugs: first-hand collection. Kharkiv: KhNEU im. S. Kuznetsya, 2016.164 s. [in Ukrainian]

4. Teich, T. Extended Value Chain Management - ein Konzept zur Koordination von Wertschöpfungsnetzen. Chemnitz: Verlag der GUC. 2003.

5. Feigenbaum, A.V. Total Quality Control (4th Edition, revised). NY: McGraw-Hill Professional. 2004.

6. Latham, A. (1996). Postfordism in the US Arms Industry: Toward "Agile Manufacturing" (YCISS Occasional Paper № 43; P. 11). Retrieved from: http://yorkspace.library.yorku.ca/ xmlui/bitstream/handle/10315/1406/YCI0065.pdf?sequence=1

7. Inman, A. Flexible Manufacturing. In Encyclopedia of Management. Retrieved from: http://www.referenceforbusiness.com/management/Ex-Gov/Flexible

Manufacturing.html\#ixzz28n88uTmH 
8. Bondarenko S. A. Style Innovation Development: Anti-Crisis Mechanisms Security: Monograph. Kharkiv: view of PromArt, 2017. 607 p. [in Ukrainian]

9. Nikishyna O.V., Bondarenko S.A., Liganenko I.V. The development of grape growing and gardening in Odessa region (logistic approach). // Innovative management: theoretical, methodical, and applied grounds : колективна монографія / edited by Illiashenko S.M., Strielkowski W. Prague : Prague Institute for Qualification Enhancement, 2018, P. 140-151.

10. Bondarenko S., Liganenko I. Background and problem aspects of innovative development the industrial enterprises of Ukraine // Transformational processes the development of economic systems in conditions of globalization: scientific bases, mechanisms, prospects: collective monograph / edited by M. Bezpartochnyi, in 2 Vol. / ISMA University. - Riga: «Landmark» SIA, 2018. - Vol. 1. - pp.307-327.

11. Strategy has become Logistics and Plan for Ukraine. Project for the eye. URL: https://mtu.gov.ua/files/Logistics.pdf [in Ukrainian]

12. Hai L. An Approach Towards Overall Supply Chain Efficiency - A Future Oriented Solution And Analysis In Inbound Process [Text] / L. Hai, S. Yirong. Göteborg University : Elanders Novum AB Pub, 2002. 87 p.

13. Characteristics of a logistics-based business model / [E. Sandberg, T. Kihlén, M. Abrahamsson] // Journal of marketing channels. 2011. № 18. P. 1-23

14. The Global competitiveness Report 2016-2017 [Electronic resource] //World Economic Forum. URL: https://www.weforum.org/reports/the-global-competitivenessreport-2016-2017-1

Публікацію підготовлено в межах виконання НДР «Формування ефективної логістики товарних ринків» (№ держреєстрації 0119U000227) 